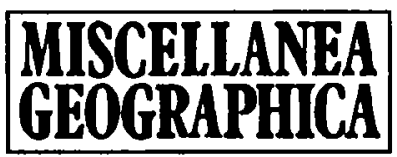

WARSZAWA 1994 Vol. 6

Maria-Stopa Boryczka, Maria Kopacz-Lembowicz, Elżbieta Błażek, Bożena Kicińska, Elwira Żmudzka

\title{
THE HEAT ISLAND IN WARSAW AND ITS EFFECTS
}

\section{INTRODUCTION}

The article presents characteristics of the heat island in Warsaw and its effect on the inhabitants of the city.

The heat island occurring in towns causes increased thermal energy resources stemming from energy transformation in the system of the active surface (very strongly transformed) and the atmosphere, as well as from surplus of waste heat in industrial and communal processes. The indicator of quantity of increased resources of thermal energy is the higher air temperature in relation to the surrounding area. This causes numerous consequences - meteorological and practical alike - important for the city inhabitants.

The knowledge of specificity of the urban environment and its effect on human beings permits an elaboration of the ways of optimization of bioclimatic conditions, including improvement in the quality of the air and alleviation of burdensome perceptible conditions, particularly in the warm season when the contact of the inhabitants of the town with external atmospheric conditions is particularly close.

\section{THE METHOD AND MATERIAL}

Estimation of the intensity of the heat island and of the effects of its occurrence was based on differences of temperature $\Delta T$, calculated for a suburban station Warsaw-Okęcie, for the entire city and for its various fragments. The town's centre was characterized on the basis of the results of measurements from the meteorological station at Warsaw University (dense development) and the Warsaw Observatory (a complex of parks), while loose development, lying far from the centre, is represented by the station of Warsaw-Bielany. 
Differences in temperature $\Delta \mathrm{T}$ were essential for determination of the equations of the regression sinusoids of daily and annual changes, for definition of correlation between $\Delta \mathrm{T}$ and other elements as well as threshold values at which the heat island is more conspicuous.

Differences in heat resources also provided grounds for the analysis of conditions of heat perception by human organism, estimated by way of effective temperature, as well as demand for thermal energy in order to maintain such temperature in houses as to ensure thermal comfort.

Initial observation data come from meteorological stations of the Institute of Meteorology and Water Management as well as from the investigations of the Department of Climatology of the University of Warsaw. They comprise chiefly the years 1961-1965 and 1969.

\section{CHARACTERISTICS OF THE URBAN HEAT ISLAND}

The heat island is not a stable phenomenon; it exhibits periodic and specific fluctuations. Periodic changes are recorded in the daily and annual cycles alike. As has been shown in previous articles (Stopa-Boryczka 1989, Stopa-Boryczka 1990) in Warsaw the heat island is strongest in the summer, averaging $1^{\circ} \mathrm{C}(\Delta \mathrm{T})$ in the town's centre (Table 1), while in the scarcely built-up area, located far from the centre, it is smaller by half.

Differentiation within the town is greater in the case of extremum values of the air temperature (Table 2).

Analysis of the annual course of values of the air temperature increase in the town provided information about the rate of the warming and cooling of the city in comparison with non built-up areas. The areas with dense development are characterized by a slower rate of the cooling and warming, particularly in the summer months.

This is specially well seen in the daily course of differences in temperature (Fig.1). In summer, differences in the average air temperature in the town may be almost $1^{\circ} \mathrm{C}$ lower than those outside the town. Positive differences usually appear about 17.00 hours and maintain until the morning, attaining the highest value $\left(+3.0^{\circ} \mathrm{C}\right)$ at midnight. This heat-preserving effect of the development may be best observed during advection of the cool air (Fig.2) which occurred e.g. on 14 December, 1963. On that day, the difference in temperature between the town's centre and suburbian stations exceeded $9.0^{\circ} \mathrm{C}$. The temperature did not become equal until after 16 hours.

The intensity of the heat island is affected by a number of meteorological elements as well as other (anthropogenic) elements (e.g. the size of the town, its density, location etc.). 
Table 1

Mean air temperature differences between the city and its surroundings calculated from the equations of regression sinusoids: daily mean $\Delta T$, maximum $\Delta T_{\max }$, minimum $\Delta T_{\text {rain }}$ (Warsaw, 1961-1965)

\begin{tabular}{|l|c|c|c|c|c|c|c|c|c|}
\hline \multicolumn{4}{|c|}{ Close development } & \multicolumn{3}{c|}{ Scattered development } & \multicolumn{3}{c|}{ Parks } \\
\hline & $\Delta \mathrm{T}$ & $\Delta \mathrm{T}_{\max }$ & $\Delta \mathrm{T}_{\min }$ & $\Delta \mathrm{T}$ & $\Delta \mathrm{T}_{\max }$ & $\Delta \mathrm{T}_{\min }$ & $\Delta \mathrm{T}$ & $\Delta \mathrm{T}_{\max }$ & $\Delta \mathrm{T}_{\min }$ \\
\hline & 0.72 & 0.34 & 0.94 & 0.30 & 0.06 & 0.50 & 0.72 & 0.46 & 0.70 \\
II & 0.73 & 0.33 & 1.04 & 0.28 & 0.10 & 0.59 & 0.74 & 0.54 & 0.75 \\
III & 0.78 & 0.26 & 1.23 & 0.29 & 0.12 & 0.74 & 0.76 & 0.59 & 0.87 \\
IV & 0.86 & 0.14 & 1.49 & 0.33 & 0.13 & 0.93 & 0.78 & 0.60 & 1.02 \\
V & 0.93 & 0.01 & 1.72 & 0.39 & 0.11 & 1.09 & 0.80 & 0.57 & 1.17 \\
VI & 0.99 & -0.10 & 1.89 & 0.44 & 0.08 & 1.19 & 0.80 & 0.50 & 1.27 \\
VII & 1.02 & -0.16 & 1.93 & 0.49 & 0.04 & 1.20 & 0.79 & 0.42 & 1.30 \\
VIII & 1.00 & -0.15 & 1.84 & 0.51 & 0.00 & 1.12 & 0.77 & 0.34 & 1.25 \\
IX & 0.95 & -0.08 & 1.64 & 0.49 & -0.02 & 0.96 & 0.75 & 0.29 & 1.14 \\
X & 0.88 & 0.04 & 1.39 & 0.45 & -0.03 & 0.78 & 0.73 & 0.28 & 0.98 \\
XI & 0.80 & 0.17 & 1.15 & 0.40 & -0.0 & 10.61 & 0.72 & 0.31 & 0.83 \\
XII & 0.74 & 0.28 & 0.98 & 0.34 & 0.02 & 0.51 & 0.71 & 0.38 & 0.73 \\
I-XII & 0.87 & 0.09 & 1.44 & 0.39 & 0.05 & 0.85 & 0.76 & 0.44 & 1.00 \\
\hline
\end{tabular}

Table 2

Mean air temperatures differences between dense development, loose development and green areas, calculated from the equations of regression sinusoids: daily mean $\Delta \mathrm{T}$, maximum $\Delta \mathrm{T}_{\max }$, minimum $\Delta \mathrm{T}_{\min }$ (Warsaw, 1961-1965)

\begin{tabular}{|l|c|c|c|c|c|c|c|c|c|}
\hline \multicolumn{4}{|c|}{ Close dev. - Scattered dev. } & \multicolumn{3}{c|}{ Close dev.- parks } & \multicolumn{2}{c|}{ scattered dev. - parks } \\
\hline & $\Delta \mathrm{T}$ & $\Delta \mathrm{T}_{\max }$ & $\Delta \mathrm{T}_{\min }$ & $\Delta \mathrm{T}$ & $\Delta \mathrm{T}_{\max }$ & $\Delta \mathrm{T}_{\min }$ & $\Delta \mathrm{T}$ & $\Delta \mathrm{T}_{\max }$ & $\Delta \mathrm{T}_{\min }$ \\
\hline I & 0.42 & 0.28 & 0.44 & -0.00 & -0.12 & 0.24 & -0.42 & -0.40 & -0.19 \\
II & 0.46 & 0.23 & 0.44 & -0.00 & -0.21 & 0.29 & -0.46 & -0.44 & -0.16 \\
III & 0.49 & 0.13 & 0.49 & 0.03 & -0.33 & 0.37 & -0.47 & -0.47 & -0.12 \\
IV & 0.53 & 0.01 & 0.56 & 0.08 & -0.46 & 0.47 & -0.45 & -0.48 & -0.09 \\
V & 0.55 & -0.10 & 0.64 & 0.14 & -0.56 & 0.56 & -0.41 & -0.46 & 0.08 \\
VI & 0.55 & -0.18 & 0.70 & 0.19 & -0.60 & 0.62 & -0.35 & -0.43 & 0.08 \\
VII & 0.53 & -0.20 & 0.73 & 0.22 & -0.58 & 0.63 & -0.30 & -0.38 & -0.10 \\
VIII & 0.49 & -0.15 & 0.72 & 0.23 & -0.49 & 0.59 & -0.27 & -0.34 & -0.14 \\
IX & 0.46 & -0.06 & 0.68 & 0.20 & -0.37 & 0.50 & -0.26 & -0.32 & -0.17 \\
X & 0.42 & 0.17 & 0.61 & 0.15 & -0.24 & 0.40 & -0.28 & -0.31 & -0.20 \\
XI & 0.40 & 0.18 & 0.53 & 0.09 & -0.14 & 0.31 & -0.32 & -0.32 & -0.22 \\
XII & 0.40 & 0.26 & 0.47 & 0.03 & -0.10 & 0.26 & -0.37 & -0.36 & -0.22 \\
I-XII & 0.48 & 0.04 & 0.58 & 0.11 & -0.35 & 0.44 & -0.36 & -0.39 & -0.15 \\
\hline
\end{tabular}

Wind (Fig.3) and cloudiness ( Fig.4) are among those meterological elements which affect the heat island most. The increase of wind velocity reduces chances for the accumulation of the heat reserve in the town, particularly in the cool season of the year. When the wind velocity exceeds $7 \mathrm{~m} / \mathrm{sec}$., 


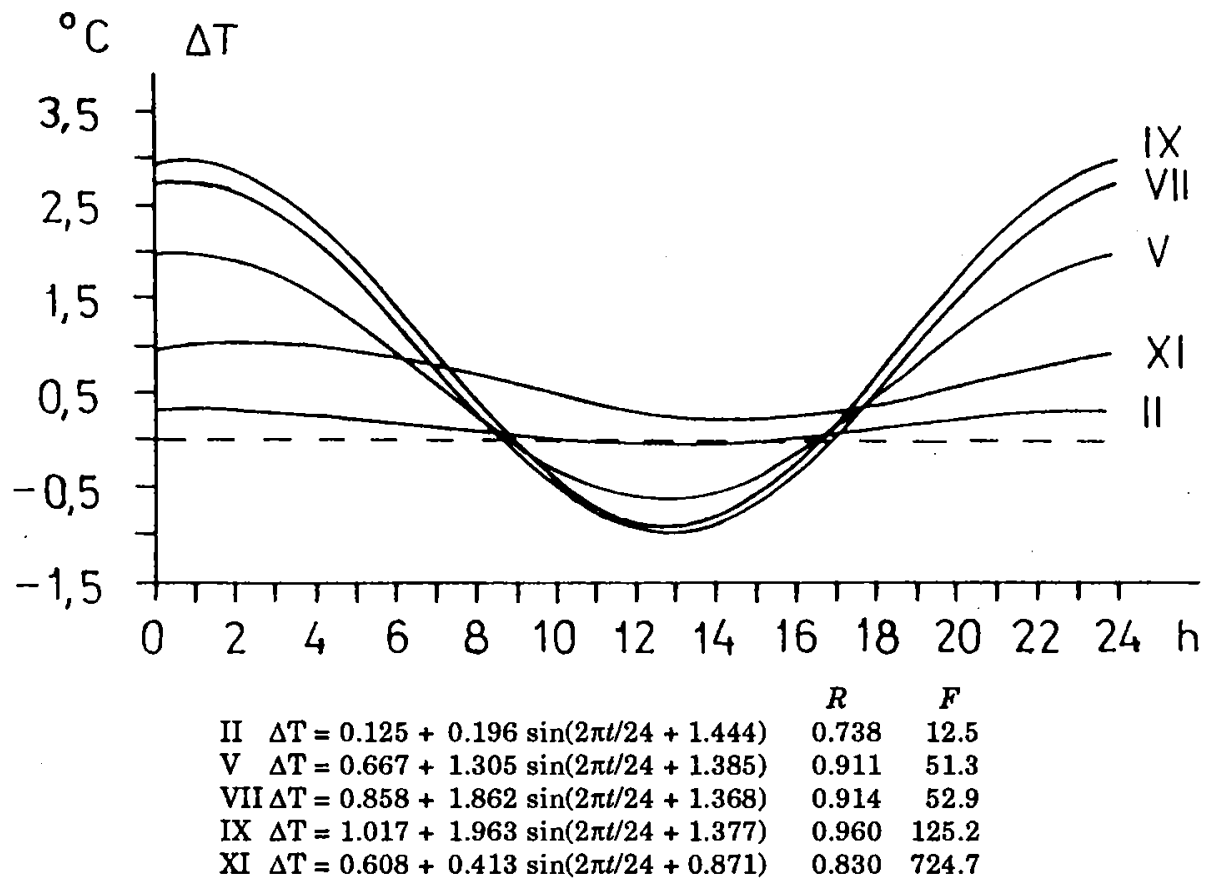

Fig.1. Sine curves of daily changes of the mean air temperature differences $(\Delta T)$ between the city and the suburbs: II - February, V - May, VII - July, IX - September, XI November (Warsaw, 1969)

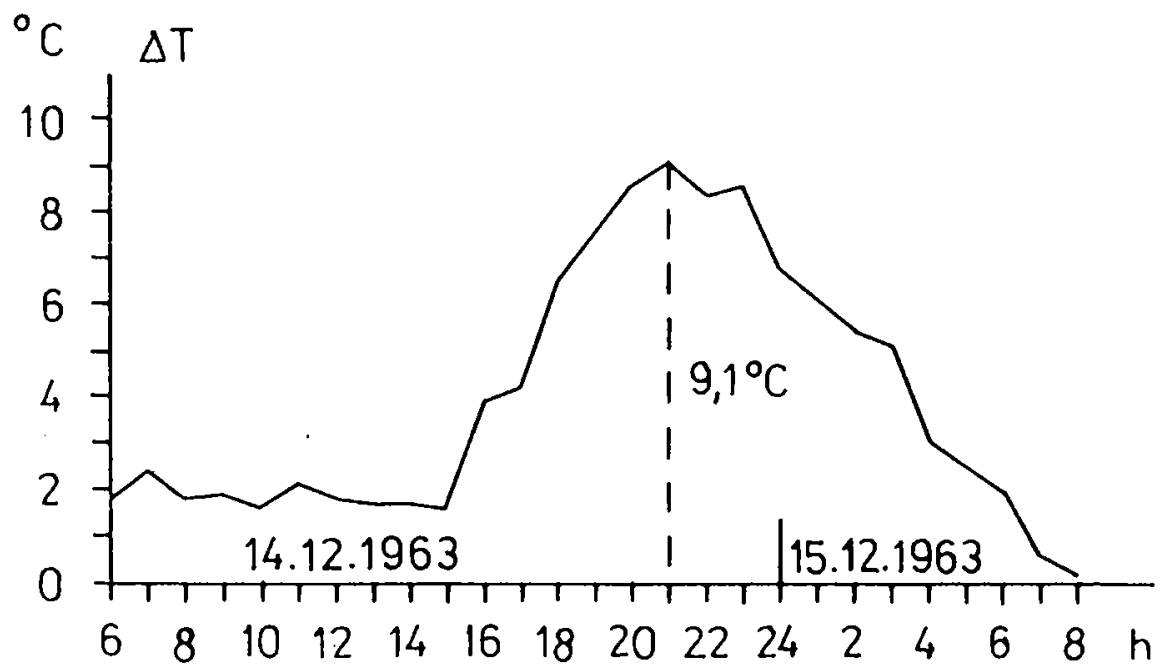

Fig.2. The course of daily changes of air temperature differences $(\Delta T)$ between the city and its surroundings in Warsaw on 14-15 December, 1963 


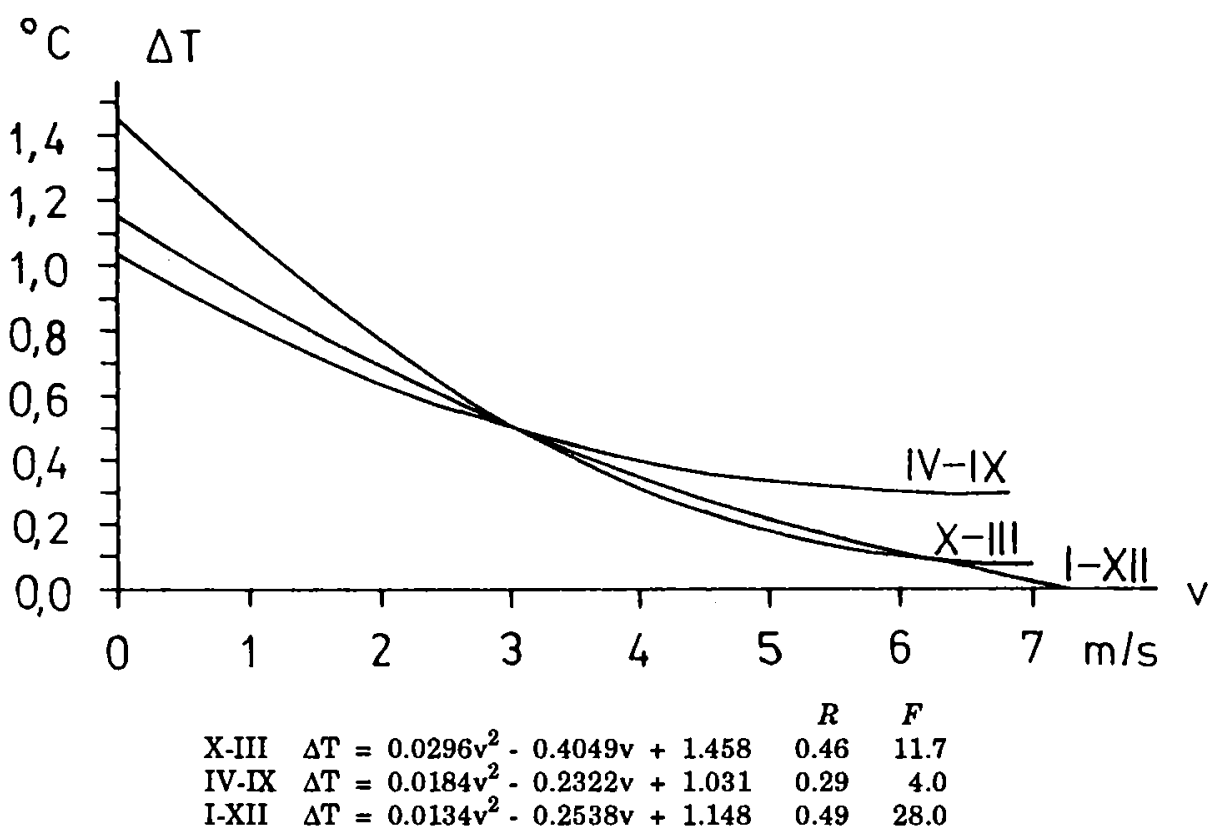

Fig.3. Parabolic dependence of differences of the mean daily air temperature $(\Delta T)$ between the city and its vicinity on the wind velocity (v) (Warsaw, 1961-1965)

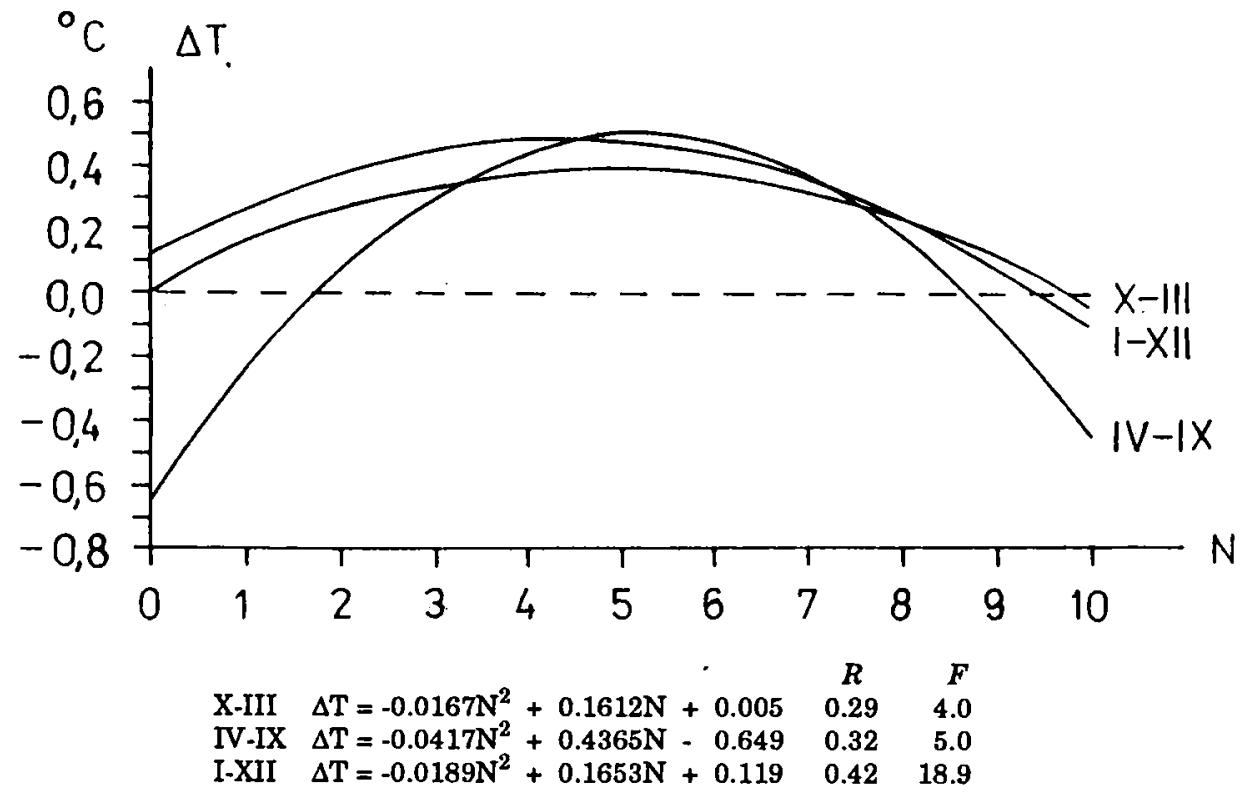

Fig.4. Parabolic dependence of differences of the mean daily air temperature $(\Delta T)$ between the city and its vicinity on cloudiness (N) (Warsaw, 1961-1965) 
the difference in the air temperature between the town and its surroundings disappears.

Cloudiness reduces the intensity of the heat island or is even conducive to the rise of negative differences. Moderate clouds are the smallest obstacle to the creation of the heat island.

The characteristics of the heat island presented herein are of special importance for the analysis of consequences of the occurrence of the heat island for the city inhabitants.

\section{EFFECTS OF THE URBAN HEAT ISLAND}

The heat island is largely affecting the process of the air exchange in the built-up area in terms of its hygienic state.

There are two systems of aeration in the built-up areas: external and internal. The external system is the wind which, by permeating the physically different environment, undergoes modification. The internal system is the local circulation within the urban organism, determined thermally and dynamically. According to the atmospheric macro-circulation, the two systems may participate in the process of aeration of the town, or one of them becomes prevalent, sometimes becoming a ventilating factor almost completely.

Warsaw, due to its location and relief, is open to a free air flow from all directions. However, it is important to what extent the air flowing over the city may be an aeration factor. If we assume that the winds of the velocity lower than $5 \mathrm{~m} / \mathrm{sec}$. in the open area, having lost 30 percent of their velocity within the built-up area, will be insufficient to ventilate the central districts, it will appear (Fig.5) that the flow of winds useful for aeration is small.

Diminishing wind velocity in the town in relation to suburban areas is observed regardless of the season of the year, the general trend towards increasing velocity in the cool season being maintained.

In the daily course the decline of the wind velocity in the evening is typical. But it is usually smaller in the town than in its vicinity; e.g. in 1969 the average wind velocity at three stations was as follows:

\begin{tabular}{lccc} 
Station & $7 \mathrm{~h}$. & $13 \mathrm{~h}$. & $21 \mathrm{~h}$. \\
\hline Brwinów & 2.9 & 4.5 & 2.5 \\
Bielany & 2.7 & 3.8 & 2.5 \\
University & 2.5 & 3.0 & 2.5
\end{tabular}

Disappearance of differences between the central and the suburban zone in the evening indicates the intensification of local circulation between the areas characterized by a different rate of cooling. Such vertical motion of 
the air occurs in Warsaw on the scale of the city, as well as in all adjacent thermally contrasting areas. On the scale of the city the breeze type circulation depends on intensity of the heat island. In the daily course it attains the highest intensity at midnight (Fig.1), and in the annual course it is most conspicuous in the summer (Table 1). It is advantageous due to extremely weak aeration of the town in the summer by the external ventilation system.

A varying degree of the warming up of the neighbouring active areas (small heat islands) during the day also contributes to the vertical air exchange.

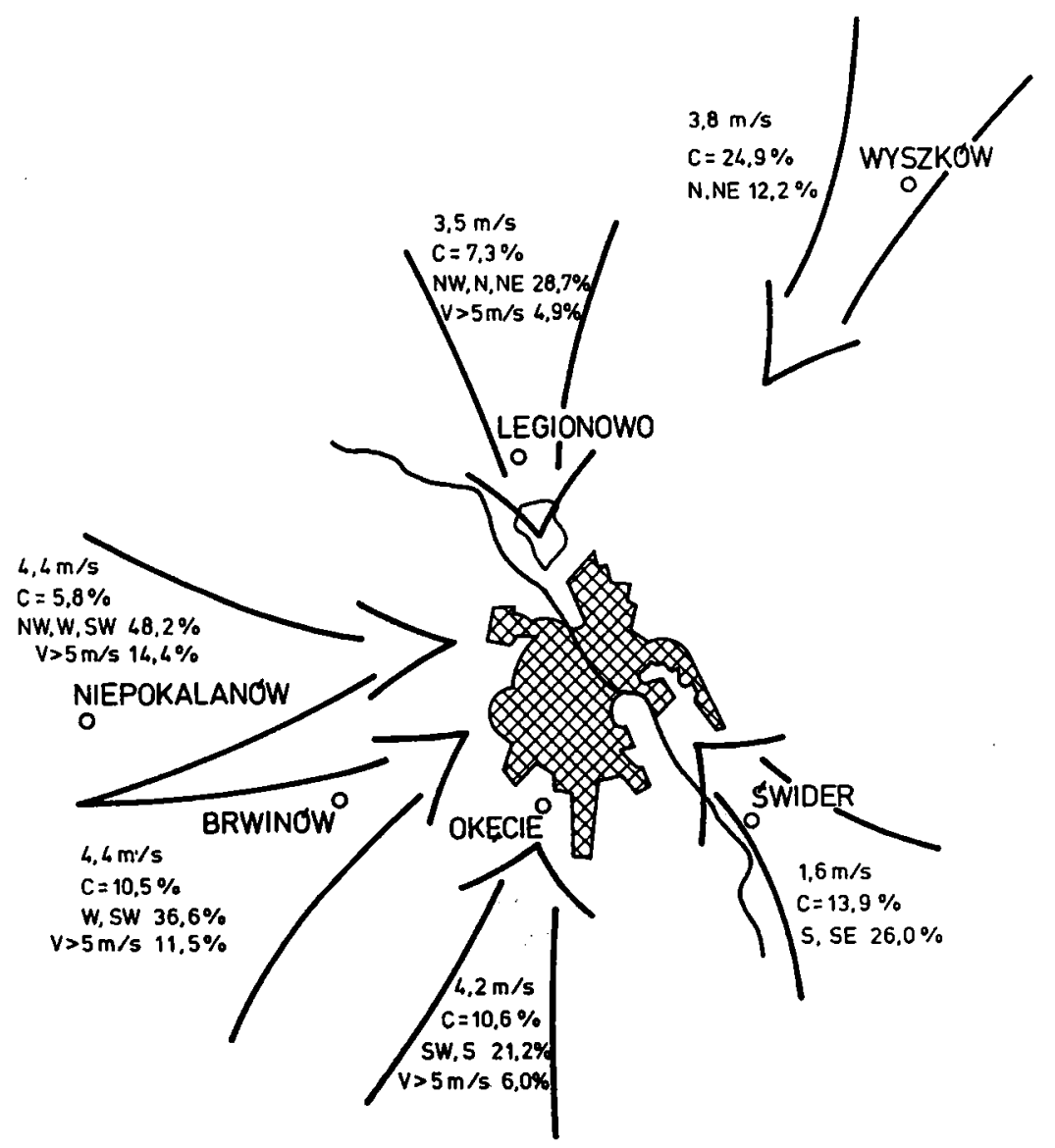

Fig.5. Scheme of wind now over Warsaw (1951-1960) 
This local (horizontal and vertical) air movement is the most important factor of self-cleaning of the air in the warm season in the case of windless weather or weak air movement. Moderate winds participate in the process, while stronger winds - exceeding $7 \mathrm{~m} / \mathrm{sec}$. - take over this function.

The role of the heat island in the process of aeration of urban areas should be evaluated positively, especially in the warm season of the year.

A direct effect of the increased temperature in the town (given the smaller wind velocity) is the change of quality of thermal incentives perceived by the human organism. In the winter, spring and autumn it may ease perceptible conditions, while in the summer it may cause thermal discomfort for people. This discomfort consists in inappropriate heat exchange between human organism and the atmospheric environment due to insufficient cooling capacity of the air.

In the centre of Warsaw these disadvatageous states occur during 20 percent summer days on the average, while outside the town they are twice as rare. In the winter the share of the states of thermal feeling of "cold" (according to M.Baranowska perceptibility scale) is by half smaller than in the suburbs; besides, these states are less durable, i.e. they maintain throughout a lesser number of successive days.

Greater resources of thermal energy in the town also indicate changes in demand for this energy for the heating of buildings. To ensure thermal comfort in flats in the cool season, a sufficient amount of heat should be conveyed to compensate for its losses.

The average heat losses in a flat (of a surface of 18 square metres, the surface of external wall 11.25 s.m., including $4.5 \mathrm{~s} . \mathrm{m}$. occupied by the window), situated in the centre of Warsaw are lower by 35 percent on the average from October to April (Fig.6), while in the middle of the winter even by 40 percent than in a similar flat in a building located in the suburbs. This means that demand for energy throughout the entire heating season in town (for the flat considered) is lower by 1200 kilowatt-hours in the town's centre (the region of the Astronomical Observatory) and by 580 kilowatt- hours in the loose development (Bielany) in relation to the vicinity of the Okeqcie airport. In the middle of the winter the differences are greatest, exceeding 10 kilowatt-hours per month.

A similar analysis, concerning the increase of exploitation costs, can be made for the warm season of the year to estimate higher use of energy in the town to ensure temperature in flats giving thermal comfort by the air conditioning system.

\section{CONCLUSION}

The effects of the heat island in a built-up area are not unequivocal, that is very negative or very positive. 
The awareness of consequences of the occurrence of this phenomenon allows us to shape some processes to a certain extent: reinforce positive or alleviate negative.

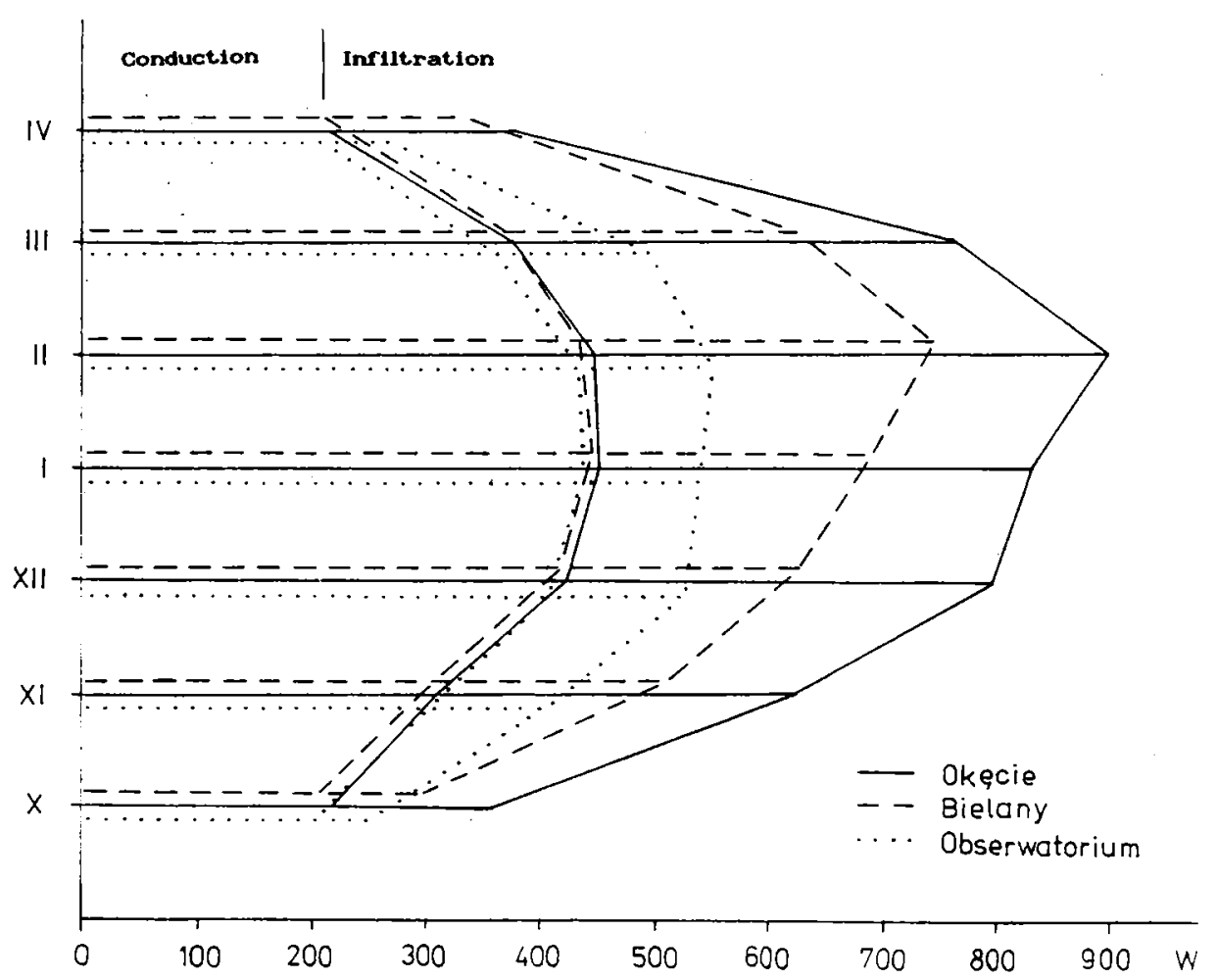

Fig.6. Average heat losses in flats in the cool season in Warsaw (1961-1965)

\section{REFERENCES}

Kopacz-Lembowicz M., 1991, "Ogólne zasady cyrkulacji powietrza w strefie wielkomiejskiej" (General principles of the air circulation in urban zone), in: System wymiany $i$ regeneracji powietrza $w$ Warszawie (The System of the Air Exchange and Regeneration in Warsaw), Instytut Miasta, Warszawa, typescript.

Kopacz-Lembowicz M., 1991, "Wymiana powietrza w Warszawie" (The air exchange in Warsaw), in: System wymiany $i$ regeneracji powietrza $w$ Warszawie (The System of the Air Exchange and Regeneration in Warsaw), Instytut Miasta, Warszawa, typescript.

Okolowicz et al., 1970, "Wplyw warunków pogodowych na rozprzestrzenianie sie zanieczyszczen powietrza na terenie Warszawy" (The influence of weather conditions on the spread of the air polution in Warsaw), the work of a team at the Department of Climatology, typescript. 
Stopa-Boryczka M., Boryczka J ., 1989, "Wpływ czynników antropogennych na klimat lokalny Warszawy" (The influence of anthropogenic factors on the local climate of Warsaw), Acta Universitatis Carolinae, Geographica, 2.

St opa-B oryczka M., B oryczka J., 1990, "Deformacja pola temperatury powietrza $w$ Warszawie pod wpływem czynników antropogenicznych" (Deformation of the field of the air temperature in Warsaw under the influence of anthropogenic factors), in: Problemy wspótczesnej topoklimatologii (Problems of Modern Topoclimatology), Instytut Geografii i Przestrzennego Zagospodarowania PAN. 